\title{
Tactical Web Use in Bumpy Times - a Comparison of Conservative Parties' Digital Presence
}

\author{
Isabelle Borucki and Jasmin Fitzpatrick ${ }^{1}$
}

\section{Introduction}

Modern day party politics happen on two grounds: the offline sphere and the online sphere. It is the primary understanding of this paper that both spheres complement each other. Especially, new emerging and often right-wing populist parties (e.g. the Swedendemocrats in Sweden, the Alternative for Germany or UKIP in the UK) as well as other emerging parties (Five Star Movement in Italy, Podemos in Spain) learnt to integrate web-based technologies during their political rise and used these technologies to bypass the mainstream media (e.g. Gerbaudo 2018). These populist and right-wing parties have become a focus in scholarly literature on parties' use of the web (e.g. Engesser et al. 2017; Hartleb 2020 in this volume; Thuermer 2020 in this volume). Many analyses so far, focused on opposition parties, who have the classical role and function of attacking the competitor. This contribution takes a different perspective: Large established parties and governing parties face the challenge to implement web-based technologies under special circumstances: they have to re-invent themselves without losing their character and identity. They already have a large heterogeneous (and therefore difficult to administer) membership base, which is diverse in its demands. Traditional local units and their meetings are familiar to many members. At the same time, web-based communication and organization might attract new supporters.

We therefore focus our contribution on governing parties and help closing this gap between online and offline communication and organization by asking: How do conservative, governing parties deploy social media over many successful election campaigns? We explore whether there are tactical patterns or tendencies of media presence between different party channels during campaign and normal times with a longitudinal approach. Second, we will introduce a multimodal comparative research design and deliver theoretical arguments for the cases considered. Third,

\footnotetext{
${ }^{1}$ Alphabetical order, both authors contributed equally to this contribution. Isabelle Borucki was responsible for parts of the theory, case design and method, and the Facebook study and analysis. Jasmin Fitzpatrick developed the research question, assumptions, literature review, theory, parts of the case design and conducted the website analysis.
} 
we will conduct a multi-channel analysis of political parties' online presence with a focus on party websites and Facebook fan pages.

\section{Mainstream Parties in the digital: Public Image, Leadership and Membership}

Party membership, leadership, and the public image are key elements of party organization. All three aspects underwent changes triggered by technology and digitalization and parties may benefit from migrating these aspects into the digital (cf. Fitzpatrick 2020 in this volume for an overview). Membership, leadership and public image were always important dimensions covered by party change research (Michels 1911, Kirchheimer 1965, Panebianco 1988, Katz and Mair 1995). In the following literature review, we will point out how parties were influenced by technological change and digitalization.

The first dimension we would like to address in this paper is the Public Image parties portray online. Those individuals loosely affiliated with a party probably do not have access to internal party material. However, they are important supporters of parties. These individuals rely at least in part on information provided by the party to the public in general. In this vein, we agree with Scarrow (2014) who also stresses the importance of party websites. Yet, we are convinced that websites allow for more than the analysis of member involvement. Parties can advertise aspects of their political program, push their elites, point to events, and deliver background information on decisions, guide users to social media platforms ${ }^{2}$, and much more. A smart mix of content and design enables a party to create a certain image through this online front window.

Parties' websites were analyzed by scholars in the past with different emphasis (e.g. Rutter et al. 2018; Koc-Michalska et al. 2016; Scarrow 2014; Ackland and Gibson 2014; Lee 2014; Følstad et al. 2014; Gibson et al. 2013; Cardenal 2011; Lilleker et a. 2011). Lilleker and colleagues (2011) identify four key functions of websites, which were also used by others as a coding scheme (e.g. Følstad et al. 2014). These four functions are (a) informing, (b) engaging (c) mobilizing, and (d) interacting. They vary in terms of their activation of the user. While a user is rather a passive consumer of information, engaging encompasses the aspect of inspiring users as well as motivating them to re-visit the website and 'to dive deeper'. Still, no real action is required. The mobilizing function eventually turns a user into an activist, while the interacting function creates dialogue between the user and organization representatives (Lilleker et al. 2011, 198-199). For our own analysis, we expect parties' websites to cover the four functions: inform, engage, mobilize, and interact. Accordingly, we suspect to identify information content (news, programs,

\footnotetext{
${ }^{2}$ This aspect is especially important for the analysis of cross-media communication.
} 
etc.). Not only, but especially during campaign season, we expect parties to increase content which is supposed to engage 3 people and to a similar degree mobilize individuals by either donating or active involvement. Since interaction is a costly aspect, we believe that opportunities will be provided, however, appear rather hidden. Instead, we expect links to social media platforms as a functional equivalent. Based on these strands of literature, we derive assumptions for our analysis. Since some of our data do not allow for statistical testing, we do not necessarily regard these assumptions as hypothesis in a strictly quantitative fashion.

Assumption 1: Parties websites intend to inform, engage, mobilize and interact with visitors.

Assumption 2: Interactive elements will be rather hidden or absent. Instead, links to social media appearances will be frequent.

Over time, we expect parties to first experiment with different tools and then focus on a few well- working ones. Facebook and Twitter became established and influential platforms and we expect websites to link to these platforms during the whole observation period. Other platforms, like google+, Flickr, Tumblr or Snapchat might be embedded at some observation points, however not consistently. This has also the effect of parties appearing trendy and always present on the newest channel. This results in our expectation to find Instagram as the latest addition to the social media portfolio.

Assumption 3: While Facebook and Twitter provide continuance, parties experiment with other social media platforms.

The four functions (informing, engaging, mobilizing, and interacting) correspond with three aspects in the Public Image pillar (Fitzpatrick 2020, in this volume): Accessibility is created by interaction with the users as well as up-to date and relevant information presented on the website. Transparency is realized by displaying information on policy preferences as well as internal procedures on decisionmaking. Parties' responsiveness regards their capability of dealing with input by members and supporters. This means, for example, they provide contact information, contact forms or link to platforms where asynchronous dialogue is possible. All three aspects of the Public Image (accessibility, transparency, responsiveness) correspond with the concept of branding. In a recent study, Rutter and colleagues (2018) state the transferability of this marketing term to online party research. This

\footnotetext{
${ }^{3}$ Out of the four aspects, this is probably the most difficult to identify. Lilleker and colleagues (2011: 198) point to visual and audio elements embedded in the website in order to make visitors revisit the page. This type of content is more entertaining. In marketing literature, "engagement is defined as the process of developing a cognitive, affective and behavioural [sic!] commitment to an active relationship with the website" (Demangeot and Broderick 2016:820). We, therefore, coded elements that we regard as intended to create a relationship with the visitor.
} 
approach acknowledges that (a) human characteristics can be transferred to organizations such as political parties, (b) adherents respond positively to these characteristics, and (c) parties employ branding techniques to create a relationship with their adherents. Rutter and colleagues (2018) conduct a dictionary-based analysis of website content for British political parties. Their results show differences between the parties. The Conservatives, for example, emphasize their (economic) competence. According to Rutter and colleagues $(2018,204)$ this can be expected from a party in government. We expect the same for other conservative parties and as well for other channels than parties' websites. Labour's emphasis is on competence and ruggedness (Rutter et al. 2018, 204-205). Referring to other authors, Rutter and colleagues $(2018,207)$ state that "[a] party's personality is formed through the interaction among electorate, the party leader, the party, and its policies" and that "[r]uling parties or more established parties may also find it more difficult to maneuver their personality."

While Rutter and colleagues (2018) focus only on the content, it is also worth including aspects of web design. This includes the placement, font size, and color as well as the use and content of pictures. Websites might provide this information directly or link to other websites. These hyperlinks were the research object of Ackland and Gibson (2014), who distinguish three types of hyperlinks, which they term according to their functions: reinforcement, forced multiplication, and opponent dismissal. Ackland and Gibson (2014) do not include social media into their study. However, Twitter, Facebook, Instagram and others may serve the same purpose as links to other websites. In our study, we will draw connections between cross-media deployment of websites and Facebook.

While some argue that party membership decline results in party decline, a more recent perspective focuses on how parties are adapting to the new circumstances without prophesy dooming parties' decline (e.g. Gauja 2015). Recruitment of new members as well as the integration of members pose challenges to all parties. Mair (1994) pointed to several cases of parties considering members as vital for parties' legitimation and the mobilization of voters as well as for their funding. Mair (1994, 16) already observed the trend of empowering ordinary members rather than the middle-level elite because ordinary members are less likely to oppose decisions and positions made by the party leadership. ${ }^{4}$ This observation is especially valuable when we look at the changed concept of party membership after parties adopted more and more web-based technologies because these often intend to strengthen the grassroots and loose affiliates. This optimistic view was based on the low access costs and the ubiquitous and asynchronous nature of digital communication. While some studies still diagnose an advantage of larger parties (e.g. Margolis et al. 2003;

\footnotetext{
${ }^{4}$ Gauja (2015) points out that Mair's work leads to a specific path for parties: instead of relying on members, they search for alternative sources to cover their demands and remain in place. This cartel party thesis (Katz and Mair 1995) has widely influenced party research, however, a different perspective allows for a new understanding of parties' adaption processes. Gauja (2015) suggests connecting party organization research with participation research. We follow this thought.
} 
Koc-Michalska et al. 2016), others observe advantages for small and new parties (Margetts 2006). Analyzing Spanish parties, Cardenal $(2011,98)$ finds "that large, non-ideological, non-bureaucratic and challengers tend to have greater incentives to use the internet for political mobilization." Cardenal (2011) calls the "under-exploiting" use of the internet by parties paradoxical. She explains that while the internet holds promising potential for maximizing support, parties are not using this potential to its full extend (Cardenal 2011,84). Faucher (2015) focuses on the mode parties use to approach individualized citizens. She observes tendencies of blurring the membership concept and an opening of decision-making processes within parties - especially regarding leadership selection $(2015,408)$. In a similar notion, Scarrow (2014) presents a "new schema [of party membership, which] rejects rigid distinctions between party activists, other members, and loose supporters" (Scarrow $2014,14)$. Her literature review results in the suggestion for a modified version of Duverger's concentric circles, the quantum model of activism $(2014,32)$ and she presents the so- called multi-speed membership model. This model consists of eight different modes, which an individual can choose from to support the preferred party. The role adopted by an individual can overlap with other (simultaneous) roles and change quickly into a different mode (Scarrow 2014, chpt. 2). The multi-speed approach is characterized by a party's attempt to increase traditional membership as well as to explore new ways of engagement ${ }^{5}$ (Scarrow 2014, 128). In her analysis, Scarrow relies on websites to analyze what means parties use to encourage party membership and affiliation (Scarrow 2014, chpt. 6). Overall, parties provide different opportunities to join, donate and volunteer (Scarrow 2014, 148).

Respecting these different speeds of membership, we expect parties to gather different forms of resources through websites. This becomes visible in calls for donations, participation and membership via buttons and sign-up-forms.

Assumption 4: We expect to find different content tailored for different target groups according to the multi-speed membership model.

We expect similar patterns on Facebook, where parties custom their content for different membership and supporter groups. For those loosely affiliated, they will provide information on policy issues and leaders which users can easily consume, like or share - especially since research indicates that those groups might be more active than members (Webb, Poletti, \& Bale, 2017). For members, we expect parties to announce exclusive events, mobilize for intraparty elections etc. In general, we expect that parties use websites as content hubs, and Facebook to hint towards press releases, party programs etc. published on the websites, and to mobilize both members and supporters.

\footnotetext{
${ }^{5} \mathrm{New}$, spontaneous, and selective forms of party participation may correspond with the logic of "connective action" described by Bennet and Segerberg (2012), as long as the party as an organization is not the center of political activism practiced by an individual $(2012,752)$.
} 
Assumption 5: We expect Facebook profiles to cater to different groups similarly to websites.

Assumption 6: We expect websites to serve as content hubs and Facebook to refer to website content and as a mobilization device.

A large supporter base is still important for the multi-speed membership party (Gomez \& Ramiro 2017; Scarrow 2018). We think that mining websites is useful beyond the analysis of membership, but also provides information on leadership styles and the portrayal of a public image. As Panebianco (1988) and Baker (2014) put it, party leadership and party membership follow different incentives to engage in a party. Careerists in a party seek status, material incentives and power, whereas rank and file members seek rather an ideological home striving for solidarity, ideology and identity. Accordingly, Baker (2014) finds out that influencers and multipliers play a big role in supporting candidates running for office when relying on $\mathrm{PACs}^{6}$ as supporting infrastructures. From a functional perspective, it is acknowledged that one of the key functions of political parties in democracies is the recruitment of political personnel, who are willing and capable of taking responsibilities within democratic institutions (e.g. Norris 1997; Ignazi 2017). Leaders and candidates, therefore, are crucial within the party and outside the party for the state and society.

Digital technologies enable parties to encourage members to become more involved through new modes of leader selection e.g. by e-voting. Leadership literature focuses rather on mechanisms of their selection and election such as primaries and the respective voting technique (Aylott \& Bolin, 2016; Chiru, et al. 2015; Chiru \& Gherghina, 2017) or the instrumentalization of primaries towards party membership (Astudillo \& Detterbeck, 2018). For candidates and leaders, web-based communication technologies also provide a considerable and nowadays crucial channel for campaigning and relationship management. Especially in election times, confronted with a "high- choice environment" (Aldrich, Gibson, Cantijoch, \& Konitzer, 2016; Van Aelst et al., 2017), a straight communication strategy - both internal and external of a party - is of highest importance to gain voters and maintain supporters and activists.

For our purposes, it will be crucial to see who leaders are and how they are displayed via the official party communication channels. Referring to Koger and colleagues (2009), we assume parties as political networks. This holds against the above-mentioned notion of parties as vertically organized hierarchies. Our approach to investigate the travelling between media platforms fits into the picture of networked communication and parties as political networks that provide information via their public presence that is their website and Facebook fan pages.

In parliamentary systems, we expect parties to push more than one central figure as leaders, although the Presidentialization hypothesis (Poguntke and Webb 2005;

${ }^{6}$ Political Action Committees. 
Webb and Poguntke 2013) suggests the opposite. Duties are often shared between different leaders of the parties' board and public office holders. Office holders should receive more attention than other party-internal leaders. These leading figures will likely be displayed in a central position on the landing page of a party.

Assumption 7: We expect parties to promote leading figures.

Assumption 8: Opposing the Presidentialization hypotheses, we expect more than one leading figure in parties to be promoted because of the environment of parliamentary systems.

Building on recent research on candidate selection (e.g. Laustsen \& Bor 2017; Ksiazkiewicz et al. 2018), we suspect candidates to be displayed as competent, but also as warm and generally likable. This means we expect "in action"-pictures rather than portraits and smiling, positive gestures sooner than photos with a fierce face expression during a speech, for example. Here, we suggest that during campaign seasons, pictures with ordinary citizens are more common, and during normal political routine pictures with other leaders will be more common.

Assumption 9: We expect candidates to be portrait as competent and warm.

\section{Case Design and Case Description}

An analysis of governing parties with an incumbent bonus, conservative background and large member and supporter base provides an in vivo ${ }^{7}$ analysis of longestablished parties who face the challenge to incorporating web-based technologies in well-established routines. We think this adds to the existing literature usually focused on other party families, populist parties or recently emerging parties. For our analysis, we focus on two parties: The Conservative Party in UK and Germany's Christian Democrats (CDU). We chose a UK and a German party, because both are parliamentary systems, and both party systems experience diversification. Both countries are governed by a conservative party that is challenged by populist and anti-migration forces within the party as well as by other political forces in the country. Both countries have recently experienced shifts in party leadership. While in UK the Conservatives were first led by David Cameron and later by Theresa May, Angela Merkel was continuously the head of government. However, the secretary general of Merkel's CDU Peter Tauber was replaced by Annegret Kramp-Karrenbauer after the 2017 Bundestag election, and Angela Merkel stepped down from her leadership position within the party in favor of Kramp-Karrenbauer. This allows for

\footnotetext{
${ }^{7}$ In contrast to the quasi in vitro implementation of web-based technologies that small parties with a moderate number of visitors and media attention can conduct without too much turmoil.
} 
observations during leadership transition. In terms of internet penetration rates, we also find similar conditions: Towards the end of 2017, in Germany 96.2 percent and in UK 94.7 percent of the population had internet access. In UK, 66 percent of the population had a Facebook account while almost 38 percent of the German population had a Facebook account. ${ }^{8}$ Amongst MPs, Facebook and Twitter are the most important social media channels, especially in campaigning (Stier et al. 2018; Kalsnes et al. 2017) in both countries.

Although appearing as a paired comparison on a party level at first sight (most similar case design), we actually observe different campaigns between 2013 and 2018, providing a longitudinal observation. During this time, social media and the ability to use them was already widespread, which enables a tactical use rather than sheer random deployment. During this period, in Germany and UK the Conservatives had competitors on the right wing of the spectrum, with a German AfD that shifted from anti-Euro policy preferences to an entirely xenophobic policy program after 2015. At the same time, the UK experienced turmoil after the Brexit-referendum. Our sample also contains election campaigns at different levels (local, national, European). We therefore conduct a "small n"- comparison with the relevant points of measurement included.

\section{Data and Methods}

Our analysis is initially based on two types of data: image capture of parties' websites and Facebook fan page posts. For each type, we will briefly explain the retrieving process.

Website images were captured via archive.org for each year between 2013 and 2018. This timeframe covers two general elections in Germany (2013 and 2017), two general elections in the UK (2015 and 2017) and one election for the European parliament (2014). Screen captures of the parties' main website were taken during the second half of April (depending on availability) in order to observe whether content first published on the website was later posted or linked on Facebook. However, also links on the first level from the websites were tested when possible. With this method, a convergence between media channels can be traced. Table 1 displays the exact date of the screen captures.

8 These data were retrieved from https://www.internetworldstats.com/stats4.htm\#europe (accessed: 10/31/2018). 


\begin{tabular}{|c|c|c|c|}
\hline & domain & year & date \\
\hline \multirow{6}{*}{$\mathrm{CDU}$} & \multirow{6}{*}{ cdu.de } & 2013 & Apr 16 \\
\hline & & 2014 & Apr 23 \\
\hline & & 2015 & Apr 18 \\
\hline & & 2016 & Apr 25 \\
\hline & & 2017 & Apr 18 \\
\hline & & 2018 & Apr 24 \\
\hline \multirow{6}{*}{ Con } & \multirow{6}{*}{ conservatives.com } & 2013 & Apr 23 \\
\hline & & 2014 & Apr 18 \\
\hline & & 2015 & Apr 21 \\
\hline & & 2016 & Apr 22 \\
\hline & & 2017 & Apr 22 \\
\hline & & 2018 & Apr 23 \\
\hline
\end{tabular}

Table 1: Dates and domains for Screen Captures of parties' main page

As displayed in table 1, the domains of the parties remained stable and the retrieving date was nearly annual to the exact day.

In a next step, a coding scheme was created based on the theoretical frame and assumptions (see above). During the coding process, additional codes (in italics, see table A2 in the appendix) were added where the empirical material suggested the necessity, e.g. the existence of a web shop. However, we are convinced that these aspects are well suited to engage people and make them publicly display their support for a party. This is why we decided to add an own code. ${ }^{9}$

The second part of our data consists of two panels of Facebook fan pages between 2013 and 2015 and 2016 and 2018. The researched period of each panel was from 24. April to 25 . May of every year to compare between phases of campaigning and every-day politics. Facebook data were retrieved using NetVizz (Rieder 2013). We collected both data from the CDU and from the Conservatives fan pages within the above-mentioned periods and coded the posts and their content with the same coding scheme as for the websites. ${ }^{10}$

\footnotetext{
${ }^{9}$ We also decided to distinguish between non-display of an aspect (0), a display as one element on the website (1) and a prominent display (2), for example in connection with a picture, video, link or an emphasis by size or color and weight this accordingly.

${ }^{10}$ We thank Tatevik Tophoven-Sedrakyan and Maximilian Wilshaus for their support during the coding process.
} 


\section{Findings}

First, we provide an impression of our Facebook data and overall tendencies. After this, we distinguish different periods based on our observations.

Looking at the total counts of posts, likes, comments, shares and reactions ${ }^{11}$ on parties' Facebook fan pages, we see an ambivalent picture (table 3 ). Both parties had considerable activities during the European electoral year in 2014, whereas the national election years 2013 and 2017 in Germany and 2015 and 2017 in Great Britain suggest a different strategy of using social media: What we can see for the European election in 2014 is that the UK Conservative Party had 50 posts but the German CDU had 114 (see Table 3). The general elections in both countries were accompanied by 123 (2015) and 86 (2017) posts in the UK and 64 (2013) and 52 (2017) posts in Germany. It is plausible that the low post number of the UK Conservative party during the European campaign can be explained with an overall Euroscepticism and reservation against European issues.

\begin{tabular}{lllllll}
\hline Party & Year & Posts & Likes & Comments & Shares & Reactions \\
\hline Cons & 2013 & 9 & 3830 & 25042 & 996 & NA \\
& $\mathbf{2 0 1 4}(\mathbf{E P )}$ & $\mathbf{5 0}$ & $\mathbf{2 5 9 2 6}$ & $\mathbf{1 8 4 1 9}$ & $\mathbf{4 9 3 9}$ & NA \\
& $\mathbf{2 0 1 5}(\mathbf{G E )}$ & $\mathbf{1 2 3}$ & $\mathbf{6 7 9 1 6 1}$ & $\mathbf{1 3 5 0 6 0}$ & $\mathbf{1 3 2 5 3 7}$ & NA \\
& 2016 & 28 & 13334 & 14959 & 2572 & 14181 \\
& $\mathbf{2 0 1 7}(\mathbf{G E )}$ & $\mathbf{8 6}$ & $\mathbf{2 2 6 0 5 3}$ & $\mathbf{1 5 3 2 8 6}$ & $\mathbf{6 4 6 9 5}$ & $\mathbf{2 5 9 0 3 0}$ \\
& 2018 & 80 & 72662 & 65250 & 18223 & 84005 \\
\hline CDU & $\mathbf{2 0 1 3}(\mathbf{G E )}$ & $\mathbf{6 4}$ & $\mathbf{6 5 6 7}$ & $\mathbf{3 0 5 8}$ & $\mathbf{2 8 8 8}$ & $\mathbf{N A}$ \\
& $\mathbf{2 0 1 4}(\mathbf{E P})$ & $\mathbf{1 1 4}$ & $\mathbf{4 0 5 8 3}$ & $\mathbf{1 0 7 8 0}$ & $\mathbf{9 2 0 7}$ & $\mathbf{N A}$ \\
& 2015 & 23 & 9786 & 5234 & 1518 & NA \\
& 2016 & 30 & 8491 & 10354 & 1478 & 9413 \\
& $\mathbf{2 0 1 7}(\mathbf{G E})$ & $\mathbf{5 2}$ & $\mathbf{2 4 1 2 9}$ & $\mathbf{1 1 4 5 6}$ & $\mathbf{4 3 0 4}$ & $\mathbf{2 6 7 4 6}$ \\
& 2018 & 51 & 19205 & 18775 & 7595 & 25776 \\
\hline Total & & 710 & 1129727 & 471673 & 250952 & 419151 \\
\hline
\end{tabular}

Table 3: Descriptive counts of analyzed Facebook fan pages (GE=General Election; EP=European Parliamentary Election).

\footnotetext{
${ }^{11}$ These include user-added emoticons to posts and likes. Engagement could be displayed as a ration or sum of all activities around posts, but within knowing the exact amounts of fans of fan pages, this is not valid, and was not intended with this data.
} 
Additionally, we find a slight, yet visible increase of posts between General Election years in both countries. After elections, the number of postings remains stable. This slight increase in election periods is interpreted as a possible indicator for more personalization, because we assume most campaign activities happen on the personal candidate fan pages i.e. of Angela Merkel, David Cameron and Theresa May and not on the party channels, yet parties link to candidate profiles. This is in line with our assumptions 7 and 9 about the prominent display of leading figures, and a warm and caring presentation of popular party leaders.

The distributing behavior of the fan page owners does not differ a lot over the years. We see a clear preference of both parties for audio-visual formats, i.e. photos and videos in the years 2016 to 2018, whereas in the first panel links also played an important role (see Tables in the Appendix). We explain this with the logic of Facebook. Posting a link provokes not the same reach and impact as photos or videos due to Facebook algorithms. This is related to our assumption 6: Facebook is first used to refer to other web content through links.

Overall, we find quite clear time ranges marking different eras in online developments for the parties observed.

\section{Germany's CDU 2013-2015: Highlighting Success}

In April 2013, the CDU was in the early stages of their campaign for the upcoming Bundestag election in fall that same year. When accessing the website, a pop up-window encouraged users to participate in drafting the election program. The slogan translates into "what lies close to my heart". This wording creates a caring, emotional frame (warmth). The party was clearly relying on Merkel's leadership capacities and nimbus. We were able to generate the screen below the pop up- window. The emphasis of the website was clearly to mobilize visitors, although the pop-up window first aims at also emotionally engaging visitors. Calls to join the party or the TeAM (Team Angela Merkel) were placed prominently as well was the call for donations. The video imbedded was considered to match the code "image film", although we were not able to research the exact content via archive.org. On the party's Facebook page, 15 videos were posted during our investigated period. The CDU hosted several social media profiles such as Facebook, GPlus, and Twitter. This was the only time in our sample where the CDU pointed to their MeinVZ presence (German social media platform).

In 2014, the elections to the European Parliament dominated the web appearance of the CDU. The party's secretary general Peter Tauber took a prominent position in communicating the CDU's policy stands via the website. The party mobilizes for instance by advertising the possibility of postal voting or joining the party as a member. Another emphasis is on information. In the news section, pieces on policy achievements after the Bundestag election 2013 framing the CDU as reliable. One news comment refers to Merkel's speech regarding the budget, which was estimated to be debt free. This later aspect displays competence in economy and finance. This strong suit was emphasized by the leading image at the top of the page, where the 
election posters were presented. The messages were "Security and a stable Euro" and "Good work and strong economy". Both slogans and campaign posters were also displayed and distributed on the Facebook page. Information and mobilization were the main interests of the CDU's communication on both channels.

For 2015, we were not able to capture the full website, so our data availability is limited. What we can state is that Helmut Kohl was in the center of attention. The former chancellor and party veteran is up to today considered a legend for his achievements leading to the German re-unification. The leading news of the party was the 85th birthday of Kohl. The image connected to the congratulation was a picture of Kohl smiling and surrounded by citizens. This picture generates warmth - a leader in the midst of his adherents. Other content dealt with the digitalization of Germany and family policies. The policy issues were also distributed via Facebook, but no congratulation message to Helmut Kohl. Overall, the intention of the website and especially the fan page was engaging visitors and informing them.

\section{Germany's CDU in a Transitional Phase in 2016}

In 2016, the party's website was revamped with a new design, which remained until the end of the observation period. The dominating color is orange. At the top of the page, users are invited to sign up for the party's newsletter. In the orange bar below the newsletter registration, users are provided with the options to join the party, donate, log on the internal platform, contact the party or browse through the CDU shop. Social media appearances (Facebook, Twitter, Instagram and Youtube) are embedded as well as the web presence of Angela Merkel. The CDU had to take heavy losses during state elections in 2016. However, in Saxony-Anhalt, prime minister Reiner Haseloff was able to secure his position despite heavy losses. The website is dominated by an article congratulating him on his win in connection with pointing to his achievements especially in economy. This congratulation was spread also on the party's Facebook fan page, using the same sentence from the website. Next to the picture of the winning candidate is a request for donations. This brings us to the conclusion that the CDU's intention was to inform.

\section{Germany's CDU 2017-2018: Continuity in Design, Change in Function and Personnel}

2017 was dominated by the election to the German Bundestag. A strong leader on the website was again Peter Tauber. Merkel was not part of the website at this early stage of campaigning. Instead, the parliamentary party leader, Volker Kauder, was placed quite prominently with a news article demanding more religious tolerance from Muslims. Policies on Migration, integration and asylum were more than once implicitly or explicitly mentioned on the website. The Facebook postings focus more on domestic security since there were state elections in North-Rhine Westphalia and Schleswig-Holstein and this policy field was of high importance.

The top of the website encouraged visitors to take part in the process of drafting an election program and asking for donations. This mobilization appeal was also distributed via Facebook and Twitter (\#schreibezukunft German: "write future") 
with enchanting images and an engaging appeal. Emotional policy topics and the invitation to participate in drafting the election program suggest that the party wanted to engage and mobilize users - in line with our assumptions 4 to 6 assuming a tailored strategy to mobilize internet savvy people and engage them.

In 2018, the CDU assigned a new secretary general: Annegret Kramp-Karrenbauer. Analyzing the website, a first impression is the change of the leading color: the orange is lighter, rather a warm yellow. The top of the page remained vaguely the same (see above). However, Snapchat was added to the array of social media platforms. Further, the link to the website of Angela Merkel was no longer represented by her name, but her characteristic hand posture, the so called "MerkelRaute" (Merkel-Diamond). Below, the new secretary general is introduced. She is displayed smiling, wearing an orange leather jacket, which repeats the signature color of her party and appears less conservative and younger than Merkel's blazers. The headline points to Kramp-Karrenbauer's "Listening Tour" (ZuhoerTour), which was exclusive to CDU members and intended to create a renewed connection to the grassroots. The tour included 50 appointments and was accompanied by a Blog, videos, and within our research period with seven posts on the party's Facebook fan page to cover her \#ZuhoerTour, which is in line with our assumptions 5 to 7. The \#ZuhoerTour was clearly a display of warmth and was meant to engage the grassroots. It is also a clear invitation for interaction. Below this central part of the website, the CDU claimed issue ownership for the domestic security in Germany by highlighting the measures that were included in the coalition treaty. This finding is also backed up, again, by postings on the party's Facebook page. The website also informed about health minister Spahn's plans for the Nursing Act, which is also accompanied by a post on the Facebook page. These policy topics were rather emotional in the debate, which justifies the interpretation that an impression of warmth and caring was supposed to be created by this content. This clearly addresses the assumption 9 of candidates being displayed as competent and caring. Other content was the call for donations, the invitation to join the party and a link to find the nearest local unit. Overall, in 2018, the CDU pointed to the new party elite and intended to engage and mobilize.

\section{The UK's Conservatives 2013-2015: Campaigning on all levels}

Turning to the website of UK's Conservative party, a first observation is that users do not have to scroll, because the website provides limited content on the landing page. The general color used on the website is blue.

In 2013, the local election campaign was the center of the website and Facebook, where a video of the Prime Minister's campaigning is distributed. On the website, David Cameron is displayed in the largest image on the page talking in a conference-like setting. The message next to him points to the local Conservative office holders and how they govern "for hardworking people". This is a claim of competence. Most out of the nine posts on Facebook in 2013 address this local election campaign. On the website, the news menu to the right of Cameron's image provides 
the user with other topics: The visitor is invited to express condolences after Thatcher's death. Another news element is titled "Tax cut for $24 \mathrm{~m}$ hardworking people". This corresponds with the wording of the former mentioned news element, however, has more of a caring component. Below, the visitor is invited to sign up for the newsletter, follow the Facebook profile, attend the party conference, view campaign photos or read blog posts. In addition, a search engine is provided, where users can find their local representatives. Overall, the website shows an informing, engaging and mobilizing function (assumptions 1 and 2).

The main issue in 2014 was the election to the European Parliament and the tensions between national interests and the European Union membership. Again, Cameron is clearly the uncontested leading figure. The dichotomy between the Conservatives and Labour is a central element of the website. The news element "How much would Labour cost you" corresponds with "Take the fight to Labour", a social media campaign led by the hashtag "\#sharethefacts" which is also found in nine posts on Facebook in 2014, accompanied with the invitation to share a video, signing up for a campaign Action Day, and therefore mobilize. ${ }^{12}$ Website visitors are invited to take action and get involved in different ways: they can donate money, join the party, sign up for the newsletter, get involved in the social media campaign, or volunteer in the 2015 general election campaign. In 2014, the focus was rather the general election 2015 than the EP election. The same is true for the Facebook fan page. Users were both on the website and the fan page invited to follow Cameron on Twitter and Facebook. In sum, the function of the website is clearly to mobilize and serving as a hub (assumption 6).

The data retrieval for 2015 was not possible in an analog manner, because a popup window redirected to a sign-up form titled "Together, we can secure a brighter future", originally directing to the domain "betterfutu.re", which was shut down after the campaign and also not available through archive.org. "Brighter future" and "strong and stable government" were slogans of Cameron's General Election campaign, which were also used in nine posts on Facebook. On the website, the design of the pop-up deviates clearly from the blue design of the usual website. "Together, we can" refers probably to Obama's "Yes, we can" and is larger in font size and printed in italics. The user is not provided with clicking "no", but only with "Yes, I'm in" or "I've not decided yet" and then leave an email-address and their postcode. We interpret this as an attempt to engage and mobilize users and make them curious (assumptions 1 and 2).

UKs Conservatives in 2016 and 2017: Experimenting with Focus, Features and Functions

\footnotetext{
12 "Voting Conservative on 22nd May is the only way to get real change in Europe. Watch our new film_share the link with your friends and family_and if you_re free this weekend_sign up for one of our campaign Action Days: http://www.conservatives.com/actionday“" (Facebook post from $24^{\text {th }} \quad$ April 2014, retrieved from: https://www.face-
} book.com/8807334278/posts/10152237696409279, accessed: 04/29/19). 
The year 2016 marked an obvious change in website strategy. While before there was a clear emphasis on the party's leader Cameron, the new website focusses on the visitor. At the top of the page, the visitor is encouraged to sign-up for the newsletter. The menu up top links for the first time during the observation period the manifesto. The tab "You and Your family" and "Your Area" are speaking to the users - engaging them. "Share some facts", "Join", "Donate" and "Volunteer" are clear imperatives to mobilize the visitor of the website (assumptions 1 and 2). A new log-on area is provided for members. Where there was a rather tiny button that led to a web shop before, now a merchandise campaign catches the user's eye: "Get the T-shirt". When users shared content via their Facebook-profile, they were able to collect points and were rewarded for their activity. The call for donations was changed: users were provided with suggestions for amounts; 12, 20, 50, 100, 200, or 500 Pounds. In sum, this all leads us to the evaluation that engaging and mobilizing by rewarding supporters were clear functions of both channels.

In 2017, some of the newly added elements of 2016 disappeared, which suggests that the Conservatives experimented. While the sign-up for the newsletter remained unchanged, the engaging elements disappeared, as did the log-on area for members. The mobilizing elements (i.e. volunteer, join, donate) remained. The web shop was reintroduced with a more prominent placement on the website. The emphasis on the new leader, Theresa May, re-entered the website focus. While under Cameron the focus was rather on economy and later the EU, now it is on the EU, especially Brexit related topics, and social policies. With an image film, the party also justified another general election in 2017 and points out their "plan for Britain" - also on Facebook. The function of the website changes from engage and mobilize to mobilize and inform. Thus, this represents a backlash concerning interactive elements.

In 2018, the main structure of the website remained the same. However, the "Volunteer", "Join" and "Donate" tabs were moved and enlarged, but remained at the top of the page, as did the newsletter sign-up. Instagram was added to the list of social media profiles and it is linked on Facebook posts, too. The web shop disappeared again and was replaced by a lottery. The attention was shifted from the leader to policy issues. Main policy topics were shifted rather away from the EU/Brexit to national issues: education, health, housing. The function of the website remained: inform and mobilize (assumptions 1 and 2).

The following tables 4 provide an overview of all findings.

\begin{tabular}{|l|l|l|l|l|l|l|}
\hline CDU & 2013GE & 2014EP & 2015 & 2016 & $2017 \mathrm{GE}$ & 2018 \\
\hline inform & & $\checkmark$ & $\checkmark$ & $\checkmark$ & & \\
\hline engage & $\checkmark$ & & $\checkmark$ & & $\checkmark$ & $\checkmark$ \\
\hline
\end{tabular}




\begin{tabular}{|l|l|l|l|l|l|l|}
\hline mobilize & $\checkmark$ & $\checkmark$ & & $\checkmark$ & $\checkmark$ & \\
\hline interact & & & & & & $\checkmark$ \\
\hline
\end{tabular}

\begin{tabular}{|l|l|l|l|l|l|l|}
\hline Cons & $2013 \mathrm{LE}$ & $2014 \mathrm{EP}$ & $2015 \mathrm{GE}$ & 2016 & $2017 \mathrm{GE}$ & 2018 \\
\hline inform & & & & & $\checkmark$ & $\checkmark$ \\
\hline engage & $\checkmark$ & & $\checkmark$ & $\checkmark$ & & \\
\hline mobilize & $\checkmark$ & $\checkmark$ & & $\checkmark$ & $\checkmark$ & $\checkmark$ \\
\hline interact & & & & & & \\
\hline
\end{tabular}

$\mathrm{LE}=$ local election; $\mathrm{GE}=$ General Election, $\mathrm{EP}=$ Election to the European Parliament

Table 4: Overview of website and Facebook functions.

\section{Conclusion}

We investigated how the public image, membership and leadership of parties are displayed on their websites and their Facebook fan pages. While many other studies provide either single case studies or large-N comparisons of many parties using one channel simultaneously, our approach differs in a few aspects. We conducted a long-term observation ( six years with one time of measurement each) of two parties in two Western countries

The focus was on conservative parties with government responsibilities. This angle provided an additional perspective to the research of party digitalization which is often limited to emerging, populist parties. We addressed the question how conservative, governing parties deployed social media over many successful election campaigns, exploring whether there are tactical patterns during campaign season and normal times. We were able to identify similarities between the two cases: Both parties experiment with different applications. WE see clear phases of digital adaptation in both cases. We conclude that the extent to which mainstream conservative parties adapt to digital transformation changes between phases of election campaigning and normal politics and between channels and audiences sought for the intended strategic aim of a party. We also observed differences for example when it comes to centralization of leadership: while the CDU referred to more than one leading figure despite the strong chancellor Angela Merkel, UKs Conservatives 
focalize the attention on the prime minister. The analysis of this study was based on the four functions introduced by Lilleker and colleagues (2011): inform, engage, mobilize and interact. Interaction with the audience is neglected in both cases despite the opportunities social media provides. Yet, no clear patterns between campaign season and governing season appear. While this experimental approach show conservative parties willingness to react to technological changes, we expect to see a more tactical, designed use of digital applications. This expectation is fueled by recent developments, e.g. the "Rezo video"-incident right before the 2019 European parliament election which suggested that social media is still the Achilles' heel of the CDU.

While many other studies provide either single case studies or large-N comparisons of many parties using one channel simultaneously, our approach differs in a few aspects. We conducted a long-term observation (six years with one time of measurement each) of two parties in two Western countries on two channels. This allows for observations of trends. We found that both analyzed parties, the Conservatives and the CDU, experimented with online appearances and social networks such as Facebook. Therefore, we found no evidence for a linear evolution of parties' online communication with their members and supporters, but a back and forth of orchestrating the instruments at hand, depending on the political time (electoral year or not). Moreover, we found differences in both countries for the European Parliament elections that played a minor role in the UK compared to Germany. Another difference is the structure of the website: while the CDU provides a lot of information on their landing page, which forces users to scroll, the Conservatives provide a condensed landing page.

One observation is that in 2015 and 2016 both parties revamped the design of the website. This change expands to the Facebook fan pages. We find that there is a form of media-congruence between websites and Facebook fan pages from 2013 to 2015. With 2016 as a strategic turning point in communication via the fan pages, there is a rather independent acting and strategic use of the fan pages as an interaction and mobilizing channel. Particularly for the General Election years and the recent two years, a posting behavior to produce interaction has turned up. Sometimes a posting appeared before the content was on the website and vice-versa. Therefore, there was no clear evidence for our analyzed periods of a direct linear travelling from websites to Facebook pages.

Another difference is the focus on the prime minister by the Conservatives, while Merkel is barely present on the CDU's website where the secretary general dominates. We explain this with the different party systems of both examined cases and the rather strict separation between the party in central offices and the party in public office, i.e. the parliamentary party.

Despite these differences, there were similarities as well. Both parties for example focused on their competence in economic questions especially during the years 2013-2015. Later, social and other more emotional political issues (immigration, health, BREXIT) were brought into focus. 
Yet, the topics and issues addressed on both channels - websites and fan pages - were similar: We witnessed a change from more personalized to issue-based communication styles and back to personalization when it comes to General Elections in both cases. Facebook, following this interpretation serves as a communication medium to interact with people, mobilize and engage them, whereas websites function as a container medium to concentrate and centralize all communication efforts of the party. This clearly refers to organizational learning as the parties begin to embed and use their social media as a converging channel.

\section{References}

Ackland, R. \& Gibson, R. (2013): Hyperlinks and networked communication: a comparative study of political parties online. International Journal of Social Research Methodology, Vol. 16(3), pp. 231-244. doi: 10.1080/13645579.2013.774179.

Aldrich, J. H.; Gibson, R. K., Cantijoch, M. \& Konitzer, T. (2016): Getting out the vote in the social media era: Are digital tools changing the extent, nature and impact of party contacting in elections? Party Politics, Vol. 22(2), pp.165-178. doi:10.1177/1354068815605304.

Astudillo, J. \& Detterbeck, K. (2018): Why, sometimes, primaries? Intraparty democratization as a default selection mechanism in German and Spanish mainstream parties. Party Politics, Vol. 0(0). doi: $10.1177 / 1354068818795195$.

Aylott, N., \& Bolin, N. (2016): Managed intra-party democracy: precursory delegation and party leader selection. Party Politics, Vol. 23(1), pp. 55-65. doi:10.1177/1354068816655569.

Baker, A. E. (2014): Party Campaign Contributions Come with a Support Network. Social Science Quarterly, Vol. 95(5), pp. 1295-1307. doi:10.1111/ssqu.12067.

Bennet, W. L. \& Segerberg, A. (2012): The Logic of Connective Action. Information, Communi$\begin{array}{lllll}\text { cation and } & \text { Society, Vol. 15(5), pp. 739-768. doi: }\end{array}$ https://doi.org/10.1080/1369118X.2012.670661.

Cardenal, A. S. (2011): Why mobilize support online? The paradox of party behaviour online. Party Politics, Vol. 19(1), pp. 83-103. doi: 10.1177/1354068810395059.

Chiru, M. \& Gherghina, S. (2017): Committee chair selection under high informational and organizational constraints. Party Politics, Vol. 0(0). doi:10.1177/1354068817741765.

Chiru, M.; Gauja, A.; Gherghina, S. \& Rodriguez-Teruel, J. (2015): Explaining change in party leadership selection rules. In: W. Cross \& J.-B. Pilet (Eds.), The Politics of Party Leadership: A Cross-national Perspective (pp. 62-87). Oxford: Oxford University Press.

Demangeot, Catherine, \& Broderick, Amanda J. (2016) "Engaging customers during a website visit: a model of website customer engagement", International Journal of Retail \& Distribution Management,Vol. 44 Issue: 8, pp.814-839, https://doi.org/10.1108/IJRDM-08-2015-0124

Engesser, Sven, Nayla Fawzi \& Anders, Olof Larsson (2017) Populist online communication: introduction to the special issue, Information, Communication \& Society, 20:9, 1279-1292, DOI: 10.1080/1369118X.2017.1328525

Faucher, F. (2015): New forms of Participation. Changing demands or changing opportunities to participate in political parties? Comparative European Politics, Vol. 13(4), pp. 405-429. doi: 10.1057/cep.2013.31.

Fitzpatrick, J. (2020): The Five-Pillar-Model of Parties' Migration into the Digital. [in this volume] Følstad A.; Johannessen M.R. \& Lüders M. (2014): The Role of a Political Party Website: Lessons 
Learnt from the User Perspective. In: Tambouris E., Macintosh A. \& Bannister F. (Eds.), Electronic Participation. ePart 2014. Lecture Notes in Computer Science (pp. 52-63).

Berlin/Heidelberg: Springer.

Gerbaudo, P. (2018): The Digital Party: Political Organisation and Online Democracy: PLUTO PRESS.

Gauja, A. (2015): The Individualisation of Party Politics: The Impact of Changing Internal Decision-Making Processes on Policy Development and Citizen Engagement. British Journal of Politics and International Relations, Vol. 17(1),pp. 89-105. doi: 10.1111/1467-856X.12035.

Gibson, R. K.; Gillan, K.; Greffet, F.; Lee, B. J. \& Ward, S. (2013): Party organizational change and ICTs: The growth of a virtual grassroots? New Media \& Society, Vol. 15(1), pp. 31-51. doi: $10.1177 / 1461444812457329$

Gomez, R. \& Ramiro, L. (2017): The limits of organizational innovation and multi-speed membership:Podemos and its new forms of party membership. Party Politics, Vol. 0(0). doi: $10.1177 / 1354068817742844$.

Hartleb, F.

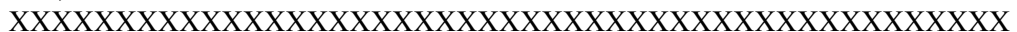

Kalsnes, B.; Larsson, A. O. \& Enli, G. S. (2017): The social media logic of political interaction: Exploring citizens' and politicians' relationship on Facebook and Twitter. firstmonday, Vol. 22(2). doi: $10.5210 /$ fm.v22i2.6348

Kirchheimer, O. (1965). Der Wandel des westeuropäischen Parteisystems. Politische Vierteljahresschrift, 20-41.

Koc-Michalska, K.; Lilleker, D. G.; Smith, A. \& Weissmann, D. (2016): The normalization of online campaigning in the web.2.0 era. European Journal of Communication, Vol 31(3), pp. 331-350. doi: 10.1177/0267323116647236.

Koger, G.; Masket, S. \& Noel, H. (2009): Partisan Webs: Information Exchange and Party Networks. British Journal of Political Science, Vol. 39(3), pp. 633-653. doi:10.1017/S0007123409000659.

Ksiazkiewicz, A.; Vitriol, J. \& Farhart, C. (2018): Implicit Candidate-Trait Associations in Political Campaigns. Political Psychology, Vol. 39(1), pp. 177-195. doi:10.1111/pops.12398.

Laustsen, L. \& Bor, A. (2017): The relative weight of character traits in political candidate evaluations: Warmth is more important than competence, leadership and integrity. Electoral Studies, Vol. 49,pp. 96-107. doi: 10.1016/j.electstud.2017.08.001.

Lee, B. (2014): Window Dressing 2.0: Constituency-Level Web Campaigns in the 2010 UK General Election. Politics, Vol.34(1), pp. 45-57. doi10.1111/1467-9256.12029.

Lilleker, D. G., Koc-Michalska, K., Schweitzer, E. J., Jacunski, M., Jackson, N., \& Vedel, T. (2011): Informing, engaging, mobilizing or interacting: Searching for a European model of web campaigning. European Journal of Communication, Vol. 26(3), pp. 195-213. doi: 10.1177/0267323111416182.

Mair, P. (1994): Party Organizations: From Civil Society to the State. In: Richard S. Katz \& Peter Mair (Eds.): How parties organize: Change and adaption in party organizations in Western democracies (pp. 1-22). Thousand Oaks: Sage Publications Ltd.

Margetts, H. (2006): Cyper Parties. In: Richard S. Katz \& William Crotty (Eds.), Handbook of Party Politics (pp. 528-535). Thousand Oaks: Sage Publications Ltd.

Margolis, M.; Resnick, D. \& Levy, J. (2003): Major parties dominate, minor parties struggle. In: Rachel Gibson, Paul Nixon \& Stephen Ward (Eds), Political Parties and the Internet (pp. 5369). Abingdon-on-Thames: Routledge.

Michels, R. (1911). Zur Soziologie des Parteiwesens in der modernen Demokratie: Untersuchungen über die oligarchischen Tendenzen des Gruppenlebens. Leipzig: Verlag von Dr. Werner Klinkhardt.

Norris, Pippa (1997): Introduction: theories of recruitment. in: Norris, Pippa (ed.): Passages to Power. Legislative Recruitment in Advanced Democracies. Cambridge University Press. p. 114 
Panebianco, A. (1988): Political Parties: Organization and Power. Cambridge: Cambridge University Press.

Poguntke, T. \& Webb, P. (2005): The Presidentialization of Politics: A Comparative Study of Modern Democracies. Oxford: Oxford University Press.

Rieder, B. (2013): Studying Facebook via data extraction: The Netvizz application. In H. Davis, H. Halpin, A. Pentland, M. Bernstein, \& L. Adamic (Eds.), the 5th Annual ACM Web Science Conference (pp. 346-355).

Rutter, R.; Hanretty, C. \& Lettics, F. (2018): Political Brands: Can Parties Be Distinguished by Their Online Brand Personality? Journal of Political Marketing, Vol. 17(3), pp. 1465-1496. doi: 10.1080/15377857.2015.1022631.

Scarrow, S. E. (2014): Beyond Party Members. Changing Approaches to Partisan Mobilization. Oxford: Oxford University Press.

Stier, S.; Bleier, A.; Lietz, H. \& Strohmaier, M. (2018): Election Campaigning on Social Media: Politicians, Audiences, and the Mediation of Political Communication on Facebook and Twitter. Political Communication, Vol. 35(1), pp. 50-74. doi:10.1080/10584609.2017.1334728.

Thuermer,

$\mathrm{G}$

(2020):

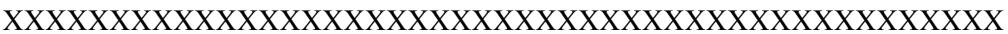

Van Aelst, P.; Strömbäck, J.; Aalberg, T.; Esser, F.; de Vreese, C.; Matthes, J. \& . . Stępińska, A. (2017): Political communication in a high-choice media environment: a challenge for democracy? Annals of the International Communication Association, Vol. 41(1), pp. 3-27. doi: 10.1080/23808985.2017.1288551.

Webb, P. \& Poguntke T. (2013): The Presidentialisation of Politics Thesis Defended,

Parliamentary Affairs, Vol. 66(3), pp. 646-654. doi: 10.1093/pa/gss059.

Webb, P.; Poletti, M. \& Bale, T. (2017): So who really does the donkey work in 'multi-speed membership parties'? Comparing the election campaign activity of party members and party supporters. Electoral Studies, Vol. 46, pp. 64-74. doi: 10.1016/j.electstud.2017.02.002. 


\section{APPENDIX}

Tables A1: Overall figures of posting types (own calculations).

\begin{tabular}{|c|c|c|c|c|c|c|c|}
\hline \multicolumn{3}{|l|}{ party } & \multicolumn{4}{|c|}{ Type } & \multirow{3}{*}{\begin{tabular}{|l|} 
Total \\
64 \\
\end{tabular}} \\
\hline & & & \multirow{2}{*}{$\begin{array}{l}\text { link } \\
14\end{array}$} & \multirow{2}{*}{\begin{tabular}{|l} 
photo \\
33
\end{tabular}} & \multirow{2}{*}{\begin{tabular}{|l} 
status \\
2
\end{tabular}} & \multirow{2}{*}{\begin{tabular}{|l} 
video \\
15
\end{tabular}} & \\
\hline \multirow{4}{*}{$\mathrm{CDU}$} & \multirow{3}{*}{ year } & 2013 & & & & & \\
\hline & & 2014 & 22 & 61 & 5 & 26 & 114 \\
\hline & & 2015 & 7 & 11 & 0 & 5 & 23 \\
\hline & \multicolumn{2}{|l|}{ total } & 43 & 105 & 7 & 46 & 201 \\
\hline \multirow{4}{*}{ Cons } & \multirow{3}{*}{ year } & 2013 & 3 & 5 & 0 & 1 & 9 \\
\hline & & 2014 & 16 & 28 & 2 & 4 & 50 \\
\hline & & 2015 & 30 & 60 & 0 & 33 & 123 \\
\hline & \multicolumn{2}{|l|}{ total } & 49 & 93 & 2 & 38 & 182 \\
\hline \multirow{4}{*}{ total } & \multirow{3}{*}{ year } & 2013 & 17 & 38 & 2 & 16 & 73 \\
\hline & & 2014 & 38 & 89 & 7 & 30 & 164 \\
\hline & & 2015 & 37 & 71 & 0 & 38 & 146 \\
\hline & \multicolumn{2}{|l|}{ total } & 92 & 198 & 9 & 84 & 383 \\
\hline
\end{tabular}

\begin{tabular}{|c|c|c|c|c|c|c|c|c|}
\hline \multicolumn{3}{|l|}{ party } & \multicolumn{5}{|c|}{ Type } & \multirow{3}{*}{\begin{tabular}{|l} 
Total \\
30
\end{tabular}} \\
\hline & & & \multirow{2}{*}{$\begin{array}{l}\text { link } \\
16\end{array}$} & \multirow{2}{*}{$\begin{array}{l}\text { photo } \\
11\end{array}$} & \multirow{2}{*}{$\begin{array}{l}\text { status } \\
0\end{array}$} & \multirow{2}{*}{$\frac{\text { video }}{3}$} & \multirow{2}{*}{$\frac{\text { note }}{\mathrm{NA}}$} & \\
\hline \multirow{4}{*}{$\mathrm{CDU}$} & \multirow{3}{*}{ year } & 2016 & & & & & & \\
\hline & & 2017 & 6 & 26 & 1 & 19 & NA & 52 \\
\hline & & 2018 & 1 & 25 & 0 & 25 & NA & 51 \\
\hline & \multicolumn{2}{|l|}{ total } & 23 & 62 & 1 & 47 & NA & 133 \\
\hline \multirow{4}{*}{ Cons } & \multirow{3}{*}{ year } & 2016 & 17 & 8 & 1 & 1 & 1 & 28 \\
\hline & & 2017 & 9 & 42 & 2 & 31 & 2 & 86 \\
\hline & & 2018 & 2 & 44 & 3 & 30 & 0 & 79 \\
\hline & \multicolumn{2}{|l|}{ total } & 28 & 94 & 6 & 62 & 3 & 193 \\
\hline \multirow{4}{*}{ Gesamt } & \multirow{3}{*}{ year } & 2016 & 33 & 19 & 1 & 4 & 1 & 58 \\
\hline & & 2017 & 15 & 68 & 3 & 50 & 2 & 138 \\
\hline & & 2018 & 3 & 69 & 3 & 55 & 0 & 130 \\
\hline & \multicolumn{2}{|l|}{ total } & 51 & 156 & 7 & 109 & 3 & 326 \\
\hline
\end{tabular}

Table 2: Deductive-inductive coding scheme used for manual coding of websites and Facebook fan pages. 


\begin{tabular}{|c|c|c|c|}
\hline Function & Code & Sub-code & Coding rule \\
\hline \multirow[t]{15}{*}{ inform } & News feed & & A news feed is embedded. \\
\hline & Social media & & Social media links/logos are embedded. \\
\hline & Manifesto & & The party manifesto is accessible (e.g. downloadable). \\
\hline & Election program & & The election program is accessible (e.g. downloadable). \\
\hline & Policy news & & The party informs about ongoing legislature. \\
\hline & $\begin{array}{l}\text { News on individuals } \\
\text { Policy }\end{array}$ & & The party informs about individual party leaders. \\
\hline & & Economy & $\begin{array}{l}\text { The party mainly informs about economy related policies (e.g. taxes, GDP, export) and frames them as } \\
\text { such. }\end{array}$ \\
\hline & & Social & $\begin{array}{l}\text { The party mainly informs about social policies (e.g. health, housing, family, retirement) and frames them as } \\
\text { such. }\end{array}$ \\
\hline & & Special interest of affiliates & The party mainly informs about policy areas of special interest to their affiliates (e.g. \\
\hline & Calendar & & A Calendar with events is provided (possibly with an archive). \\
\hline & Leaders & & \\
\hline & & Name leader 1 & Person most prominently displayed or most frequently mentioned. \\
\hline & & Name leader 2 & Person second most prominently displayed or most frequently mentioned. \\
\hline & & Name leader 3 & Person third most prominently displayed or most frequently mentioned. \\
\hline & & Name leader else & Other persons prominently displayed or mentioned. \\
\hline \multicolumn{4}{|l|}{ engage } \\
\hline & Image film & & Movie clip about the party itself, a party leader or a campaign. \\
\hline & Competence & & Party claims competence in certain aspects. \\
\hline & Warmth & & Party tries to frame itself as caring, listening, passionate, and sympathetic. \\
\hline & Leader competence & & Leader claims competence in certain aspects. \\
\hline & Leader warmth & & Leader is framed as caring, listening, passionate, and sympathetic. \\
\hline & merchandise & & The party provides merchandise like T-shirts for e.g. a specific campaign. \\
\hline & shop & & The party hosts an actual web shop with a variety of products. \\
\hline \multirow[t]{5}{*}{ 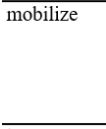 } & donations & & The party asks for donations e.g. via an online form. \\
\hline & Mailing list & & The party asks visitors to sign up for a mailing list. \\
\hline & Member log on & & The party provides a special, password secured log-on area for members. \\
\hline & Member sign up & & The party is recruiting as asking visitors to become a member. \\
\hline & Negative campaigning & & The party posts negative content about competitors. \\
\hline \multicolumn{4}{|r|}{ ( } \\
\hline & Facebook & & The party links to its Facebook page. \\
\hline & Twitter & & The party links to its Twitter profile. \\
\hline & Gplus & & The party links to its Gplus profile. \\
\hline & YouTube & & The party links to its YouTube channel. \\
\hline & Instagram & & The party links to its Instagram profile. \\
\hline & Other social media & & \\
\hline & & Names of other social media & The party links to its other social media presences (e.g. Snapchat) \\
\hline & Invitation & & The party provides user-friendly links to share content with others. \\
\hline & Contact form & & The party provides a contact form. \\
\hline & e-mail & & The party provides an e-mail address. \\
\hline & address & & The party provides a postal address. \\
\hline \multicolumn{4}{|l|}{ cross media } \\
\hline & Website content & & [Facebook specific] The party refers to website content. \\
\hline & TV content & & The party refers to TV content. \\
\hline & Classic media & & The party refers to content e.g. in (online) newspapers etc. \\
\hline
\end{tabular}

Table A2: Deductive-inductive coding scheme used for manual coding of websites and Facebook fan pages. 